\title{
Epidemiological and clinical characteristics of people with venous ulcers attended at municipal health units
}

\author{
Características epidemiológicas e clínicas de pessoas com úlcera venosa \\ atendidas em unidades municipais de saúde
}

\section{Características epidemiológicas y clínicas de personas con úlcera venosa atendidas en unidades municipales de salud}

\author{
Clara Cayeiro Cruz'1 , Maria Helena Larcher Caliri ${ }^{1}$, Rodrigo Magri Bernardes ${ }^{2}$
}

ORCID IDS

Cruz CC (D) https://orcid.org/0000-0003-2380-9948

Caliri MHL (D) https://orcid.org/000-0001-7662-5072

Bernardes RM (D) https://orcid.org/000-0001-6232-704
HOW TO CITE

Cruz CC, Caliri MHL, Bernardes RM. Epidemiological and clinical characteristics of people with venous ulcers attended at municipal health units. ESTIMA, Braz. J. Enterostomal Ther., 16:e1218. doi: 10.30886/estima.v16.496

\begin{abstract}
Objectives: To describe the sociodemographic and health data of individuals with venous ulcers treated at health services in Ribeirão Preto (São Paulo, Brazil) and to identify aspects of lower limbs and lesions and therapies used in treatment. Method: Quantitative descriptive study developed through the review of medical records, interview with users and evaluation of lower limbs. The data collection was done in the period of four months after the approval of the Institutional Committee of Ethics in Research. Results: 53 individuals with active or healed venous ulcer participated in the study. There was a predominance of individuals older than 60 years (73.5\%), women (64.2\%) and chronic diseases (73.6\%), especially systemic arterial hypertension. Thirty-seven (69.8\%) individuals had 72 active ulcers and 16 (30.2\%) had 23 healed ulcers. Ulcers were in the lower third of the leg (97.2\%), in an area $<49 \mathrm{~cm}^{2}(80.6 \%)$, with predominance of devitalized tissue (61.1\%). Several treatment options were used to protect the wound bed, debridement or absorption of the exudate. Conclusion: The study enabled possible to identify the profile of users with venous ulcer and the assistance provided to them.
\end{abstract}

DESCRIPTORS: Stomatherapy; Varicose ulcer; Patient care; Primary health care.

\footnotetext{
1 Universidade de São Paulo - Escola de Enfermagem de Ribeirão Preto - Departamento de Enfermagem Geral e Especializada Ribeirão Preto/SP - Brazil.

¿Universidade de São Paulo - Escola de Enfermagem de Ribeirão Preto - Programa de Pós-graduação em Enfermagem Fundamental - Ribeirão Preto/SP - Brazil.

Corresponding author: Clara Cayeiro Cruz | Rua Professora Vanda Gonzaga, 821 - Recanto Capitão Heliodoro | CEP: 14407-702 - Franca/SP Brazil | E-mail: clara_ccruz@yahoo.com

Received: May 25, 2017 | Accepted: Dec. 21, 2017
} 


\section{RESUMO}

Objetivos: Descrever os dados sociodemográficos e de saúde de indivíduos com úlceras venosas atendidos em serviços de saúde de Ribeirão Preto (São Paulo, Brasil) e identificar aspectos dos membros inferiores e das lesões e as terapias utilizadas no tratamento. Método: Estudo descritivo quantitativo desenvolvido por meio da revisão de prontuários, entrevista com usuários e avaliação dos membros inferiores. A coleta de dados foi feita no período de quatro meses após a aprovação do Comitê Institucional de Ética em Pesquisa. Resultados: Participaram do estudo 53 indivíduos com úlcera venosa ativa ou cicatrizada. Houve predomínio de indivíduos com idade superior a 60 anos (73,5\%), de sexo feminino (64,2\%) e com doenças crônicas (73,6\%), em especial a hipertensão arterial sistêmica. Trinta e sete (69,8\%) indivíduos apresentavam 72 úlceras ativas e $16(30,2 \%)$ apresentavam 23 úlceras cicatrizadas. As úlceras estavam localizadas no terço inferior da perna (97,2\%), numa área $<49 \mathrm{~cm}^{2}(80,6 \%)$, com predominância do tecido desvitalizado (61,1\%). Foram utilizadas várias opções de tratamento para a proteção do leito da ferida, o desbridamento ou a absorção do exsudato. Conclusão: 0 estudo possibilitou identificar o perfil dos usuários com úlcera venosa e a assistência prestada a eles.

DESCRITORES: Estomaterapia; Úlcera varicosa; Assistência ao paciente; Atenção primária à saúde.

\section{RESUMEN}

Objetivos: Describir los datos sociodemográficos y de salud de individuos con úlceras venosas atendidos en servicios de salud de Ribeirão Preto (São Paulo, Brasil) e identificar aspectos de los miembros inferiores y de las lesiones y las terapias utilizadas en el tratamiento. Método: Estudio descriptivo cuantitativo desarrollado por medio de la revisión de historias clínicas, entrevista con usuarios y evaluación de los miembros inferiores. La recolección de datos se hizo en el periodo de cuatro meses después de la aprobación del Comité Institucional de Ética en Investigación. Resultados: Participaron del estudio 53 individuos con úlcera venosa activa o cicatrizada. Hubo predominio de individuos con edad superior a 60 años (73,5\%), de sexo femenino (64,2\%) y con enfermedades crónicas (73,6\%), especialmente con hipertensión arterial sistémica. Treinta y siete (69,8\%) individuos presentaban 72 úlceras activas y 16 (30,2\%) presentaban 23 úlceras cicatrizadas. Las úlceras estaban ubicadas en el tercio inferior de la pierna (97,2\%), en un área < 49 cm² (80,6\%), con predominancia del tejido desvitalizado $(61,1 \%)$. Se utilizaron distintas opciones de tratamiento para la protección del lecho de la herida, el desbridamiento o la absorción del exudado. Conclusión: El estudio posibilitó identificar el perfil de los usuarios con úlcera venosa y la asistencia prestada a ellos.

DESCRIPTORES: Estomaterapia; Úlcera varicosa; Asistencia al paciente; Atención primaria a la salud.

\section{INTRODUCTION}

The occurrence of venous ulcer (VU) in the lower limbs is the final event of a series of vascular abnormalities that affect the integumentary system. VU is a major public health problem and has long duration. It is highly recurrent and affect, mostly, elderly people. It may be associated with other diseases or health conditions, such as diabetes mellitus (DM), arterial hypertension and obesity, among others ${ }^{1}$.

The VU is usually initiated by trauma and its main etiology is chronic venous insufficiency (CVI), an abnormality of the functioning of the venous system that can affect both the deep and superficial venous systems ${ }^{1}$.

The impairment of the lower limbs, because of CVI, is manifested by several changes that may be evidenced by the physical examination of the patient. The Chronic Venous Disease Classification System (CVDC) was created by specialists and considers the clinical signs $(C)$, the cause or etiology (E), anatomical location (A) and specific pathophysiological conditions $(\mathrm{P})$.
The clinical signs are easily observed and the classification (C) has six categories, considering: $\mathrm{C} 0$ - the absence of objective indicators of the disease; $\mathrm{C} 1$ - the presence of telangiectasia or reticular veins; $\mathrm{C} 2$ - the presence of varicose veins or varices; $\mathrm{C} 3$ - edema; $\mathrm{C} 4$ - trophic changes such as hyperpigmentation, eczema and lipodermosclerosis; $\mathrm{C} 5$ - trophic changes of $\mathrm{C} 4$ and healed ulcer; and $\mathrm{C} 6$ - trophic changes of $\mathrm{C} 4$ and active ulcer ${ }^{1}$.

Authors affirm that the exact prevalence of active VU in the population is unknown, but it is estimated that in developed countries the prevalence is less than $1 \%$ and more than $3 \%{ }^{1}$.

The VU can hamper and even prevent the attendance to basic aspects of daily life, such as locomotion and ambulation, due to chronic pain or discomfort, thus affecting the life habits of the individual. There are also damages to the coexistence, causing depression, social isolation, low self-esteem, retirement from work or early retirement and increased hospitalizations or outpatient visits, which results in a decrease in quality of life and a high social and economic impact. When not properly 
managed, $26 \%$ to $28 \%$ of healed VU recur in the first year and up to $76 \%$ of them within three to five years ${ }^{1}$.

The VU treatment, besides being long duration, is costly due to the recurrent nature and the long time elapsed between its beginning and healing. Care requires the basic treatment of venous hypertension through compressive therapy ${ }^{1}$. The Unna boot is used frequently in the health services, being indicated for patients with $\mathrm{VU}$ that roam, because it favors the venous return. It may be used in combination with other topical therapies, but is contraindicated if infection is suspected ${ }^{1,2}$.

The topical therapy consists in the cleaning of lesion and the use of coverages that allow the wound bed to remain moist and clean, in addition to promoting absorption of the exudate. To clean the surface of the wound, the most indicated solution is saline solution, because it is isotonic. In the home environment, drinking water can replace saline solution, but for patient safety it is necessary to assess its quality ${ }^{1}$.

At present, it is expected that the assistance provided by the health services incorporate in the professionals' routines the best evidence to support decisions about the most appropriate care. In the Municipal Health Department (MHD) of Ribeirão Preto (São Paulo, Brazil), since 2001, there is a protocol for topical therapy of chronic wounds, which is part of the "Handbook of Integral Assistance to Wounded People”. The protocols are seen as tools that help professionals in their decisions, aiming to guide their performance in favor of quality assistance ${ }^{2}$.

A study realized in Ribeirão Preto with individuals with chronic wounds attended at the health units identified that the most common wound was VU and that many users, by judicial request, besides the standardized topical therapy in the MHD protocol, also received treatment with hyperbaric oxygen therapy (HOT). However, most of the individuals did not present wound healing at the end of the treatment and were still followed up by the health team, even after the HOT sessions ${ }^{3}$.

Fifteen years after the creation of the "Handbook of Integral Assistance to the Wounded People" and the proposal of the protocol, a new study is needed to investigate the sociodemographic and clinical profile of VU users and the treatment that has been performed in the health services of the city.

\section{OBJECTIVES}

To describe the sociodemographic and clinical data of users with VU registered in the health services of a Sanitary District of Ribeirão Preto; describe the characteristics of the lower limbs according to CVDC; and to identify the characteristics of the lesions and the therapies used in the treatment.

\section{METHODS}

This is a quantitative descriptive study performed with individuals diagnosed with VU in treatment at the health units of a Sanitary District of the city of Ribeirão Preto. The population was composed of 98 adult or elderly users, identified in the registers of the health units, in April 2015. Users who did not attend the appointments scheduled in the health units during the period of data collection and/or those that were not located in the addresses registered as of their domiciles, after the third attempt of search were excluded.

The initial contact with the user was made by phone to explain the study objectives and to identify the date of the return to the health unit, when the patient was invited to participate in the study. For those who could not go to the unit, a home visit was scheduled. Those who agreed to participate in the study signed the Informed Consent Term. Data collection was done from October 2015 to January 2016 through review of medical records, interview with users and evaluation of lower limbs and wounds. For the data collection, adapted routines were used from previous work ${ }^{3}$. The ulcer area was classified as small $\left(<50 \mathrm{~cm}^{2}\right)$, medium $\left(>50 \mathrm{~cm}^{2}\right.$ and $\left.<150 \mathrm{~cm}^{2}\right)$, large $\left(>150 \mathrm{~cm}^{2}\right.$ and $\left.<250 \mathrm{~cm}^{2}\right)$ and extensive $\left(>250 \mathrm{~cm}^{2}\right)$.

The data collected were typed on a Microsoft Excel ${ }^{\circledR}$ 2007 worksheet, validated by double typing, and analyzed using the statistical program SPSS version 16.0, considering for categorical variables, absolute and percentage frequencies, and for continuous variables, mean, the standard deviation and the minimum and maximum values.

The research project was approved by the Research Ethics Committee on Human Beings of Ribeirao Preto Nursing College of University of São Paulo, under CAAE no 48669515.0.0000.5393. 


\section{RESULTS}

Of the 98 users registered in the health services in April 2015, it was identified that 10 had died and eight refused to participate. Twenty-seven were not found after the third attempt to search by telephone or by home visit at the address registered in the information system. Thus, 53 individuals participated in the study. Table 1 shows their sociodemographic characteristics.

The majority of individuals (64.2\%) were women. There was a predominance of the elderly (58.5\%). The minimum age of the patients was 30 years and the maximum age was 89 years (mean age 63 years and SD 14.2). As to nation, there was a similar frequency between whites and brownish, with 21 patients (39.6\%) in each category.

The educational level of the participants ranged from illiterate (13.2\%) to higher education (9.4\%), and 49.1\% of the individuals had incomplete elementary school.

As to marital status, 22 (41.5\%) were married or were in stable union, 19 (35.9\%) were separated, divorced or single and $12(22.6 \%)$ were widowers. The majority (88.7\%) had children (minimum 0 , maximum 17 and average 3.5, SD 3.1). Forty-six (86.8\%) lived with relatives, four (7.5\%) lived alone and three (5.7\%) were in long stay institutions for the elderly.
As for the profession/occupation of the participants, the majority (75.4\%) were service and trade workers, but only 13 (24.5\%) practiced. Twenty-seven (50.9\%) were retirees, seven (13.2\%) were receiving sick pay, three $(5.7 \%)$ were pensioners and three $(5.7 \%)$ were unemployed.

Regarding health conditions and life habits, 10 (18.9\%) were smokers (mean consumption of 5.8 cigarettes per day and mean of use of 29.2 years) and 14 (26.4\%) were smokers made use of alcoholic beverages, with preference for beer and estimated consumption of three glasses a day. Regarding body mass index (BMI), two (3.8\%) were underweight, 10 (18.9\%) had normal weight, 12 (22.6\%) were overweight, 24 (45.3\%) were obese and five (9.4\%) were not able to report weight and height. The minimum BMI was 16.8; the maximum, 55.5; and the mean, 30 (SD 7.5).

Thirty-nine (73.6\%) users had other conditions/ chronic diseases besides venous disease. Systemic arterial hypertension $(\mathrm{SAH})$ was the most frequent chronic condition, affecting 34 (64.2\%) individuals, followed by DM, in 14 (26.4\%). Other diseases present in nine (17\%) users were hypercholesterolemia, hypertriglyceridemia, hyperthyroidism, hyperuricemia, sickle cell anemia, pulmonary emphysema, thrombosis, depression, Parkinson's disease and Alzheimer's disease.

Table 1. Distribution of patients with venous ulcer, according to gender, age group and nation. Ribeirão Preto, São Paulo, Brazil, 2015.

\begin{tabular}{|c|c|c|}
\hline Characteristic & $\mathrm{n}$ & $\%$ \\
\hline \multicolumn{3}{|l|}{ Gender } \\
\hline Female & 34 & 64.2 \\
\hline Male & 19 & 35.8 \\
\hline \multicolumn{3}{|l|}{ Age group } \\
\hline 30 to 40 years & 01 & 1.9 \\
\hline 41 to 59 years & 21 & 39.6 \\
\hline 60 to 80 years & 25 & 47.2 \\
\hline$\geq 81$ years & 06 & 11.3 \\
\hline \multicolumn{3}{|l|}{ Nation } \\
\hline White color & 21 & 39.6 \\
\hline Brownish color & 21 & 39.6 \\
\hline Black color & 11 & 20.8 \\
\hline
\end{tabular}


In Table 2, data on the clinical characteristics of the lower limbs (LL) of the 53 patients are presented, considering the CVDC. It is noted that one patient had one limb amputated, therefore, 105 limbs were evaluated.

Of the 105 evaluated members, 46 (43.4\%) presented trophic alterations and active ulcers and 23 (21.7\%) presented trophic alterations with healed ulcers. It was identified that some users had history of other LL injuries, such as erysipelas (eight) and phlebitis (four). Two patients had a history of deep venous thrombosis, one with involvement of one limb and the other in both limbs.

Thirty-seven users (69.8\%) had 72 active ulcers (minimum one, maximum four), present between one and 60 years. In the other $16(30.2 \%)$, the ulcers were healed (minimum one, maximum three), with a total of 23 ulcers. The wound time for healed ulcers ranged from one to 37 years.

Most of the ulcers were in the lower third of the leg (97.2\%), with highlight to the medial malleolus region (36.2\%), followed by the lateral malleolus (31.9\%). Fifteen ulcers $(20.8 \%)$ were located on the back of the leg and eight (11.1\%) on the entire circumference of the limb. Fifty-eight ulcers (80.6\%) had area $<49 \mathrm{~cm}^{2}$ and seven $(9.7 \%)$ had an area $>250 \mathrm{~cm}^{2}$.

Regarding the characteristics of the $72 \mathrm{VU}, 44$ (61.1\%) had a predominance of devitalized tissue and 28 (38.9\%) had granulation tissue. As to the exudate, nine (12.5\%) did not present; 24 (33.3\%) presented small amounts; 20 (27.8\%), mean quantity; and 19 (26.4\%), great quantity. Considering the edge of the lesions, it was noted that 28 (38.9\%) wounds presented intact borders and that equal amount had macerated borders. Regarding the peripheral skin conditions, 21 (29.1\%) were intact or pink; 27 (37.5\%), hyperemia; 12 (16.7\%), dry; nine (12.5\%), torpid; and three (4.2\%) macerated. Thirteen (18.1\%) ulcers presented malodorous odor.

Regarding the level of pain during healing, 30 (56.6\%) users reported a score of 0 and six (11.3\%) reported a score of 10 . On the 0 to 10 scale, the mean pain score was 2.8 (SD 3.7).

The treatment of active ulcers of the 37 users, during the year 2015, was performed through different topical and adjuvant therapies. Twenty-four users received compressive therapy, 22 (59.4\%) using the Unna boot and two (5.4\%) with elastic stocking. Ten (18.9\%) users were treated for HBO, obtained through judicial process. The treatment time varied from one to 1080 days, with the number of sessions between one and 160. As for topical therapy (Table 3), there was at least one product and a maximum of 22 products and/or medications. The different treatment options were used for the maintenance of humid environment or protection of the wound bed, for debridement, for absorption of the exudate or to protect the skin. The products most frequently used by users were marigold (51.4\%) and silver sulfadiazine (43.2\%).

Table 2. Distribution of the characteristics of the lower limbs of the patients in relation to the clinical classification of the Classification System of Chronic Venous Diseases (CVDC). Ribeirão Preto, São Paulo, Brazil, 2015.

\begin{tabular}{lcc} 
Clinical classification & $\mathbf{n}$ & $\mathbf{\%}$ \\
\hline 0 - No evidence of venous disease (visible or palpable signal) & 03 & 2.9 \\
\hline 1 - Telangiectasia, reticular veins or malleolar explosion & 04 & 3.8 \\
\hdashline 2 - Varicose veins & 04 & 3.8 \\
\hline 3 - Edema without skin changes & 07 & 6.7 \\
4 - Changes in skin pigmentation, venous eczema and lipodermosclerosis & 18 & 17.1 \\
\hline $5-$ Trophic changes with healed ulcers & 23 & 21.9 \\
\hline - Trophic changes with active ulcers & 46 & 43.8 \\
Total & 105 & 100 \\
\hline
\end{tabular}


Table 3. Frequency distribution of treatments used for active venous ulcers. Ribeirão Preto, São Paulo, Brazil, 2015.

\begin{tabular}{|c|c|c|c|c|c|c|}
\hline \multirow{2}{*}{ Types of therapy } & \multicolumn{2}{|c|}{ Yes } & \multicolumn{2}{|c|}{ No } & \multicolumn{2}{|c|}{ Total } \\
\hline & $f$ & $\%$ & $f$ & $\%$ & $\mathrm{~F}$ & $\%$ \\
\hline Marigold & 19 & 51.4 & 18 & 48.6 & 37 & 100 \\
\hline Papaín gel & 18 & 48.6 & 19 & 51.4 & 37 & 100 \\
\hline Silver sulfadiazine $1 \%$ & 16 & 43.2 & 21 & 56.8 & 37 & 100 \\
\hline Hydrogel without alginate & 16 & 43.2 & 21 & 56.8 & 37 & 100 \\
\hline Stryphnodendron gel & 11 & 29.7 & 26 & 70.3 & 37 & 100 \\
\hline Essential fatty acid & 11 & 29.7 & 26 & 70.3 & 37 & 100 \\
\hline Hydrocolloid & 10 & 27.0 & 27 & 73.0 & 37 & 100 \\
\hline Hydrogel with calcium alginate & 10 & 27.0 & 27 & 73.0 & 37 & 100 \\
\hline Collagenase & 10 & 27.0 & 27 & 73.0 & 37 & 100 \\
\hline Foam & 08 & 21.6 & 29 & 78.4 & 37 & 100 \\
\hline Barrier cream & 07 & 18.9 & 30 & 81.1 & 37 & 100 \\
\hline Vaseline & 07 & 18.9 & 30 & 81.1 & 37 & 100 \\
\hline Active carbon & 06 & 16.2 & 31 & 83.8 & 37 & 100 \\
\hline $\begin{array}{l}\text { Fibrinolysin, deoxyribonuclease and } \\
\text { chloramphenicol }\end{array}$ & 06 & 16.2 & 31 & 83.8 & 37 & 100 \\
\hline Foam with silver & 04 & 10.8 & 33 & 89.2 & 37 & 100 \\
\hline Neomycin Sulfate and Bacitracin & 03 & 8.1 & 34 & 91.9 & 37 & 100 \\
\hline Foam with ibuprofen & 03 & 8.1 & 34 & 91.9 & 37 & 100 \\
\hline Calcium alginate tape & 03 & 8.1 & 34 & 91.9 & 37 & 100 \\
\hline Hydrofiber & 02 & 5.4 & 35 & 94.6 & 37 & 100 \\
\hline Foam with silicone & 01 & 2.7 & 36 & 97.3 & 37 & 100 \\
\hline
\end{tabular}

\section{DISCUSSION}

Regarding the sociodemographic categorization, there was a predominance of elderly women, which corroborates data from other international and national studies $^{1,4}$. In the study realized in Ribeirão Preto, of the 86 patients with chronic wounds who requested HBV treatment, $51.2 \%$ were women and the mean age of these patients was 63 years. Of the 34 patients with VU, 25 (54.4\%) were elderly ${ }^{3}$. These results confirm the epidemiology of the problem in which age and gender are risk factors for the occurrence of VU, which progressively increases with aging and affects women to a greater measure than men ${ }^{1}$.

The schooling of the participants varied greatly, ranging from illiterate to those with higher education. Predominated incomplete elementary school, followed by illiterates. Low schooling can directly interfere with the understanding of the guidelines and care relevant to people's health, compromising the degree of understanding and adherence to complex treatments, such as those required for people with VU.

Regarding the profession/occupation of the participants, the fact that most have worked in services and trade may have influenced the development of venous insufficiency and the presence of ulcer. The sedentary lifestyle with long periods of work in the standing or sitting position, without alternating with ambulation, is a predisposing condition for venous hypertension ${ }^{1}$. The type of activity or occupation exercised by the patient can influence the management of the ulcer, especially with regard to the chronicity of the injuries, often generating early retirements, unemployment and frequent medical licenses. 
Concerning comorbidities, there was a higher prevalence of SAH, followed by hypertension associated with DM. This discovery was also found in a study realized in the city of Botucatu, in which the authors verified the association between patients who had VU with $\mathrm{SAH}$ and $\mathrm{DM}$, and most of them had $\mathrm{SAH}^{4}$. The $\mathrm{SAH}$ influences the evolution of $\mathrm{VU}$, since it is associated with atherosclerosis, which causes vasoconstriction and decreased tissue oxygen supply ${ }^{1}$. This condition, associated with advanced age and DM, favors the reduction of vascular flow and a microenvironment with oxygen depletion, which makes healing difficult ${ }^{4}$. Diabetic patients with poor glycemic control may present with cellular dysfunction at all stages of the healing process. The proliferative phase is affected and results in small granulation tissue formation ${ }^{5}$.

In the present study, the mean BMI of the patients was 30 , with a high frequency of overweight and obese individuals. Obesity is associated with several diseases, such as SAH and DM type 2, as well as venous diseases and their sequelae, such as $\mathrm{VU}^{6}$. In obese individuals, the risk of wound infection is increased due to the lack of vascularization of adipose tissue, which decreases the body's defense capacity, increasing the bacterial load on the site. On the other hand, obesity may decrease the individual's mobility and ability to perform personal hygiene and proper self-care of the lower limbs.

The smoking habit occurred in $18.9 \%$ of the individuals in this study. Smoking interferes with all stages of the healing process. Nicotine, an alkaloid substance presents in all tobacco products, reduces blood flow through vasoconstriction, stimulates the release of proteases that can accelerate the tissue destruction process, suppress the immune response, and lead to an increased risk of infection. Tobacco alone decreases the production of collagen, weakens scar tissue and makes it more susceptible to recurrence of the lesion. The carbon monoxide produced during the combustion of tobacco has a greater affinity for hemoglobin, leading to the reduction of $\mathrm{O}_{2}$ in peripheral tissues ${ }^{5}$.

The use of alcoholic beverages, cited by $26.4 \%$ of individuals, can also interfere with the healing process of the wounds. The mechanism by which alcohol intake interferes with this process includes increased insulin resistance and glycemia. In addition, users of alcoholic beverages tend to present inadequate food intake, with a high risk of protein breakdown. This results in decreased inflammatory and autoimmune responses, decreased fibroblast migration and angiogenesis, and decreased collagen production, weakening scar tissue during the remodeling phase ${ }^{6,7}$.

In the present study, it was observed that most of the ulcers were located in the lower third of the leg, with predominance of the malleolus. In the literature, similar results were found, with ulcers occurring mainly in the medial malleolar region ${ }^{4}$.

The VU lifetime of the participants ranged from one to 60 years, which differs from the results of another study, in which most VU was less than one year. ${ }^{4}$. Care with VU requires the basic treatment of venous hypertension. Failure to control hypertension contributes to the long duration of the lesion and to the high relapse rates, as well as to the worsening of the patient's quality of life ${ }^{6,8}$.

Regarding ulcer evaluation, there was a predominance of lesions with small areas. In relation to the lesion bed, there was a greater predominance of devitalized tissue. It is known that the presence of necrotic tissue increases the healing time and predisposes to infection ${ }^{4}$. As to the amount of exudate, there was variation, however, it is noteworthy that 19 (26.4\%) wounds had large amounts. Excessive exudate can cause damage to the edge of the lesion and peripheral skin if the moisture is not controlled with appropriate topical and compressive therapies.

In the evaluation of the level of pain during the dressing, it was identified, on a scale of 0 to 10 , that $11.3 \%$ of the individuals reported a score of 10 (worst possible pain). A study realized in Goiania with 76 individuals with leg ulcers, of which 39 (51.3\%) had a venous etiology, identified that $75 \%$ had pain in the wounds in the period before the dressing. During the dressing, the pain intensity was higher. For those with VU, 28.2\% reported slight or moderate pain and $17.9 \%$ reported severe pain. Cleansing of the lesion was the most painful procedure, followed by the moment of removal of the previous dressing.

Compression therapy through the Unna boot was performed in the majority of users (59.4\%), who used the product in the manipulated form, with a seven days exchange interval. In the protocol of the MHD-RP, it is presented that the residence time of the Unna boot can vary between 7 and 15 days, however, when there is extreme exudation or when the patient reports loosening or garroting of the boot, the exchange can be made with interval three days ${ }^{1,2}$.

In relation to topical therapy, the protocol indicates the use of several products, from the assessment of the lesion, 
such as: active carbon, hydrogel with and without alginate, calcium alginate, hydrocolloid, transparent and adhesive film, marigold, sodium vaseline, silver sulfadiazine $1 \%$ and papain, among others ${ }^{2}$.

In the present study, the most used coatings were indicated in the MHD-RP protocol for wounds with granulation tissue or in the epithelization phase, such as marigold and hydrogel without alginate. Papain was used for enzymatic debridement. Other topical therapies, such as collagenase and Neomycin Sulfate and Bacitracin, are not standardized therapies in the municipality's MHD protocol, but were prescribed by the medical staff.

To promote the absorption of the exudate products were used such as calcium alginate, foam toppings (with and without silver), active carbon and hydrofiber. In three cases, ibuprofen foam cover was used to control ulcer pain, a product not yet included in the MHD-RP protocol, but available in some health units. Silver sulfadiazine 1\% was used by 16 (48.6\%) individuals. Antibiotic ointments and creams used to treat infected wounds do not reach adequate serum levels to control the infection and, depending on the volume of drained exudate, require the dressing to be changed one or more times a day, which increases the direct cost and indirect treatment ${ }^{1}$.

\section{CONCLUSION}

The study allowed greater visibility of the population that has VU in the health units of a Sanitary District of the city of Ribeirão Preto and the treatment provided. The results showed a higher prevalence of elderly individuals, women, with SAH and obesity. Thirty-seven users had 72 active ulcers for more than one year and most of the lesions were in the lower third of the leg region, especially the malleolus region. The ulcers presented predominance of the devitalized tissue, being the majority with exudate in average or large quantity.

Not all users with active ulcers received compressive therapy. High frequency of users reported feeling pain during the dressing change procedure. Topical treatment was done mostly with the coverage indicated in the municipality's $\mathrm{MH}$ protocol, but non-standard therapies were prescribed by the medical team. The characterization of users and their health conditions and treatment was essential to plan interventions with the services, aiming at improving the quality of care, using the best evidence in practice.

\section{AUTHOR'S CONTRIBUTION}

Conceptualization, Cruz CC, Caliri MHL, Bernardes RM; Methodology, Cruz CC, Caliri MHL, Bernardes RM; Writing, Cruz CC, Caliri MHL, Bernardes RM; Supervision, Caliri MHL.

\section{REFERENCES}

1. Carmel J. Venous ulcers. In: Bryant RA, Nix DP. Acute and chronic wounds: current management concept. 4th ed. St. Louis Missouri: Elsevier; 2012. p. 204-26.

2. Prefeitura Municipal de Ribeirão Preto, Secretaria Municipal da Saúde, Comissão de Assistência, Assessoria e Pesquisa em Feridas da Secretaria Municipal da Saúde de Ribeirão Preto. Manual de assistência integral às pessoas com feridas. 3a ed. Ribeirão Preto, 2013.

3. Fuzaro MMM, Bernardes RM, Chayamiti EMPC, Caliri MHL. Oxigenoterapia hiperbárica para tratamento de feridas crônicas: análise retrospectiva do desfecho de solicitações judiciais. ESTIMA, Braz J Enterestomal Ther. 2012;10(3):1-15

4. Borges EL, Amorim IPG, Carvalho DV. Características dos pacientes com úlcera venosa atendidos nas unidades de atenção primária de Nova Lima, Minas Gerais. ESTIMA, Braz J Enterestomal Ther. 2014;12(1):31-41.
5. Anderson K, Hamm RL. Factors that impair wound healing. J Am Coll Clin Wound Spec. 2012;4(4):84-91. doi: 10.1016/ j.jccw.2014.03.001.

6. Medeiros ABA, Frazão CMFQ, Tinôco JDS, Paiva MGMN, Lopes MVO, Lira ALBC. Úlcera venosa: relação entre os fatores de risco e a classificação dos resultados de enfermagem. Invest Educ Enferm. 2014;32(2):252-9.

7. Dryden SV, Shoemaker WG, Kim JH. Wound management and nutrition for optimal wound healing. Atlas Oral Maxillofac Surg Clin. 2013;21(1):37-47. doi: 10.1016/j.cxom.2012.12.008.

8. Araújo RO, Silva DC, Souto RQ, Pergola-Marconato AM, Costa IKF, Torres GV. Impacto de úlceras venosas na qualidade de vida de indivíduos atendidos na atenção primária. Aquichan. 2016;16(1):56-66. doi: 10.5294/aqui.2016.16.1.7.

9. Oliveira PFT, Tatagiba BSF, Martins MA, Tipple AFV, Pereira LV. Avaliação da dor durante a troca de curativos de úlceras de perna. Texto Contexto Enferm. 2012;21(4):862-9. doi: 10.1590/s0104-07072012000400017. 